\title{
KARAKTERISTIK PEKERJA INFORMAL DI KOTA TARAKAN (STUDI KASUS KAWASAN PERTOKOAN THM)
}

\section{CHARACTERISTICS OF INFORMAL WORKERS IN TARAKAN CITY CASE STUDY OF THM SHOPPING AREA}

\author{
Ida Pasha $^{1)}$, Said Usman Assegaf ${ }^{2)}$ \\ (Universitas Borneo Tarakan) \\ Email: idapasha7@gmail.com
}

\begin{abstract}
Abstrak: Penelitian ini bertujuan untuk mengetahui Karakteristik Pekerja Informal di Kawasan Pertokoan THM Kota Tarakan. Jenis penelitian ini adalah metode deskriptif dengan pendekatan kualitatif dan kuantitatif. Populasi dalam penelitian ini pekerja informal yang berada di kawasan pertokoan THM Kota Tarakan. Jumlah sampel dalam penelitian ini adalah 183 sampel dengan teknik pengambilan sampel Purposive Sampling dan tahap pengumpulan data dengan cara observasi dan kuisoner. Penelitian ini menggunakan motode persentase. Hasil penelitian menunjukkan Karakteristik yang paling banyak dari pekerja informal berdasrkan jenis kelamin yaitu laki-laki (61,20\%), berdasarkan usia 30 - 40 tahun (46,40\%), berdasarkan pendidikan yaitu SMA (38,25\%), berdasarkan suku yaitu bugis $(56,83 \%)$, berdasarkan status perkawinan yaitu sudah kawin (90,16\%), berdasarkan jumlah tanggungan keluarga yaitu 3 orang (33,88\%), berdasarkan jenis usaha yaitu konveksi $(45,36 \%)$, berdasarkan status kepemilikan yaitu milik sendiri (95,63\%), berdasarkan lama usaha yaitu 6 - 10 tahun $(54,64 \%)$, berdasarkan jumlah tenaga kerja yaitu 2 orang $(28,42 \%)$, berdasarkan hubungan responden dengan tenaga kerja adalah orang lain (66,66\%), berdasarkan keinginan menambah tenaga kerja yaitu responden tidak ingin menambah tenaga kerja (65,57\%), berdasarkann jam kerja yaitu 12 - 14 jam sehari (71,03\%), berdasarkan upah tenaga kerja yaitu Rp.1.200.000 sampai dengan Rp.1.400.000 per bulan (49,72\%), upah tenaga kerja yang mengalami kenaikan (76,50\%), sumber modal yaitu modal sendiri (67,21\%). Potensi penerimaan retribusi pelayanan pasar berdasarkan kios, los dan pelataran/halaman sebanyak 183 responden adalah Rp.164.772.000/ tahun.
\end{abstract}

Kata kunci : Karakteristik, Pekerja Informal, Potensi Retribusi.

Abstract: This study aims to determine the characteristics of informal workers in the THM shopping area of Tarakan City. This type of research is descriptive method with qualitative and quantitative approaches. The population in this study is informal workers who are in the shopping area of THM City of Tarakan. The number of samples in this study were 183 samples with purposive sampling technique and data collection stage by observation and questionnaire. This research uses percentage method. The results showed that the most characteristics of informal workers based on gender that is men (61.20\%), based on the age of 30-40 years (46.40\%), based on education, that is high school $(38.25 \%)$, based on ethnicity that is Bugis (56.83\%), based on marital status, that 
is married (90.16\%), based on the number of family dependents, that is 3 people (33.88\%), based on the type of business that is convection (45.36\%), based on status ownership, which is self-owned (95.63\%), based on the length of business, which is 6-10 years (54.64\%), based on the number of workers, that is 2 people (28.42\%), based on the relationship of respondents with other workers ( $66.66 \%)$, based on the desire to increase the workforce, the respondents did not want to increase the workforce (65.57\%), based on working hours 12-14 hours a day (71.03\%), based on labor wages of Rp.1,200.000 up to Rp.1,400,000 per month $(49.72 \%)$, the wages of workers who experienced an increase (76.50\%), the source of capital is their own capital (67.21\%). Potential acceptance of market service fees based on stands, stalls and courtyards / yard as many as 183 respondents is Rp.164.772.000 / year.

Keywords: Characteristics, Informal Workers, Retribution Potential.

\section{LATAR BELAKANG}

Indonesia dihadapkan pada masalah pertumbuhan penduduk yang cepat. Sejalan dengan pertumbuhan penduduk tersebut maka penyediaan tenaga kerja juga meningkat. Pesatnya peningkatan tenaga kerja di satu pihak dan rendahnya daya serap pasar kerja terutama di sektor formal, jika tidak diimbangi dengan perluasan lapangan kerja yang memadai tentunya akan menimbulkan masalah pengangguran. Usaha sektor informal adalah salah satu cara menangani masalah tersebut.

Usaha sektor informal sering ditemukan di daerah perkotaan yaitu merupakan daerah yang memiliki peluang besar untuk memperoleh pekerjaan, namun tak jarang ditemui penduduk miskin diperkotaan. Salah satu peranan usaha di sektor informal yaitu menciptakan kesempatan kerja dan mengatasi masalah pengangguran serta mendorong tumbuhnya wirausahawanwirausahawan baru. Dimana penciptaan lapangan pekerjaan dan pengentasan kemiskinan diperkotaan merupakan dua dari berbagai masalah yang harus ditemukan jalan keluarnya dalam pembangunan nasional.

Terlepas dari potensi kegiatan pelaku sektor informal, keberadaan sektor informal bahkan sering menimbulkan permasalahan kebersihan lingkungan dan keindahan, kesemrawutan lalu lintas, potensi konflik yang besar dan sebagainya. Keadaan ini mendorong keikutsertaan atau campur tangan pemerintah untuk melaksanakan program pembinaan dan pengembangan, penataan pada sektor informal. Salah satu manfaat keikutsertaan pemerintah dalam penataan ruang kota untuk pelaku sektor informal yaitu dengan adanya Pendapatan Asli Daerah (PAD), khususnya yang berasal dari retribusi daerah harus dipungut atau dikelolah secara bertanggung jawab.

Disamping itu dengan semakin meningkatnya pelaksanaan pembangunan kegiatan penyediaan jasa pelayanan oleh Pemerintah Daerah untuk tujuan kepentingan dan kemanfaatan umum diarahkan agar tidak menghambat bahkan 
sebaliknya dapat menunjang usaha peningkatan pertumbuhan perekonomian daerah. Dengan demikian pengenaan retribusi daerah atas penyediaan jasa pemerintah daerah perlu disederhanakan berdasarkan penggolongan jasa yang disediakan oleh pemerintah daerah, yaitu golongan jasa umum, jasa usaha, dan perizinan tertentu (Putri, 2013). Dengan ini diharapkan akan dapat meningkatkan efisiensi dan efektivitas pungutan retribusi daerah yang ada guna meningkatkan mutu serta jenis pelayanan umum kepada masyarakat.

\section{RUMUSAN MASALAH}

Sehubungan dengan uraian di atas dapat dirumuskan beberapa permasalahan dalam penelitian, sebagai berikut :

1. Bagaimana karakteristik pekerja informal di Kota Tarakan?

2. Seberapa besar potensi penerimaan retribusi pelayanan pasar THM di Kota Tarakan?

\section{TUJUAN PENELITIAN}

Adapun tujuan dari penelitian ini adalah sebagai berikut:

1. Mengidentifikasi karakteristik pekerja informal di Kota Tarakan.

2. Menjelaskan potensi penerimaan retribusi di kawasan pertokoan THM di Kota Tarakan.

\section{TINJAUAN PUSTAKA}

Konsep informalitas perkotaan ini tidak terlepas dari dikotomi sektor formal dan sektor informal yang mulai dibicarakan pada awal tahun 1970-an. Fenomena sektor informal merupakan fenomena yang sangat umum terjadi di negaranegara berkembang. Presentase sektor informal di negara-negara dunia ketiga seperti di Amerika latin, Subsahara afrika, Timur tengah dan Afrika utara dan asia selatan berkisar antara 30-70 persen dari total tenaga kerja . Di indonesia menurut data indikator Ketenagakerjaan dari badan pusat statistik (BPS), November 2003, 64,4 persen.

Keberadaan sektor formal dan informal dalam suatu sistem ekonomi akan selalu berdampingan, dimana ada sektor formal maka biasanya di situ juga ada sektor informal. Keberadaan sektor formal di kota misalnya perkantoran atau industri akan diikuti dengan timbulnya berbagai sektor informal seperti pedagang kaki lima dan pelayanan jasa-jasa kecil.

Sektor informal di kota terutama harus dipandang sebagai unit-unit berksala kecil yang terlibat dalam produksi dan distribusi barang-barag yang masih dalam suatu proses evolusi daripada dianggap sebagai kelompok perusahaan yang berskala kecil dengan masukan-masukan (inputs) modal dan pengolahan (managerial) yang besar (Sethuraman: 1998).

Ada dua pandangan atau sikap sehubungan dengan meluasnya sektor informal diperkotaan: Pandangan yang berpendapat mengalirnya angkatan kerja dari pedesaan yang memasuki sektor informal merupakan gejala positif, karena keberadaan sektor informal dipandang sebagai pelengkap dan penunjang serta sebagai sumber potensi perkembangan ekonomi kota, 
Pandangan bahwa sektor informal berdiri sendiri dan terpisah dari kegiatan ekonomi kota (Tajuddin Noer Effendi, 1996:247).

Unit-unit usaha sektor informal di kota-kota besar pada umumnya terkonsentrasi di sektor perdagangan dan sektor pelayanan jasa bagi masyarakat kota. Kegiatan yang mereka lakukan, mulai dari menjadi pedagang asongan, pedagang kaki lima, sampai buruh gendongan bersifat melengkapi kegiatan sektor formal. Unit usaha kecil pekerja dektor informal di kota, bagaimanapun tidak bisa diingkari telah turut serta meramalkan dinamika kehidupan masyarakat kota.

Menurut Undang-Undang Republik Indonesia Nomor 14 Tahun 1969 tentang Ketentuan-Ketentuan Pokok Mengenai Tenaga Kerja, tenaga kerja adalah setiap orang yang mampu melakukan pekerjaan baik di dalam maupun diluar hubungan kerja guna menghasilkan barang atau jasa untuk memenuhi kebutuhan masyarakat. Menurut Sumarsono (2003:41) kesempatan kerja adalah lapangan pekerjaan yang sudah di duduki (employment) dan masih lowongan (vacancy).

Sektor informal merupakan jenis kesempatan kerja yang kurang terorganisir sebagai sumber berwiraswasta, namun dilihat daya serapnya, khusunya di daerah perkotaan presentase pekerja di sektor informal berkembang semakin besar. Besarnya daya serap tersebut merupakan cerminan ketidakmampuan sektor formal menampung pertambahan angkatan kerja, sehingga dapat diasumsikan bahwa jika orang tidak dapat bekerja di sektor formal, dan tidak ada lowongan di sektor formal, maka orang akan mencari atau menciptakan kesempatan kerja di sektor informal, selain itu sektor informal mudah dilakukan oleh siapapun bahkan yang berpendidikan rendah dapat masuk di sektor ini, juga mampu memenuhi kebutuhan masyarakat.

Sektor informal dan formal mengisi satu sama lain. Sektor informal menghasilkan dan menyediakan barang dan jasa bagi sektor formal. Sebaliknya sektor formal dapat merangsang terciptanya peluang kerja dan berusaha bagi penduduk miskin. Sektor informal akan dapat berkembang menjadi formal sejalan dengan meningkatnya pertumbuhan ekonomi kota, karena itu sektor informal perlu dibantu dan diupayakan terkait dengan sektor formal.

Kegiatan sektor informal berperan sebagai penampung angkatan kerja yang belum bekerja baik di kota maupun di desa yang ridak tertampung pada sektor formal. Kegiatan sektor informal bukan gejala sementara melainkan gejala permanen yang terlepas dari perkembangannya. Pada tahun 1980 proporsi pekerja sektor informal terdapat jumlah angkatan kerja di kota mencapai sekitar 35,7 \%, kemudian pada tahun 1990 angkatan kerja di sektor ini meningkat menjadi 42,2 \%, dan pada tahun 1993 menjadi 43,9 5 (Tajuddin Noer effendi, 1996:260).

$\underline{\text { Kekuatan Sektor Informal }}$

Selama krisis ekonomi, terbukti sektor informal tidak hanya 
dapat bertahan, bahkan berkembang pesat. Hal ini disebabkan faktor permintaan dan faktor penawaran. Dari sisi permintaan, akibat krisis ekonomi pendapatan rill rata-rata masyarakat turun dratis dan terjadi pergeseran permintaan masyarakat, dari barang-barang sektor formal atau impor ( yang harganya relatif mahal) ke barang- barang sederhana buatan sektor informal (yang harganya relatif murah). Dari sisi penawaran, akibat banyak orang di PHK-kan di sektor formal selama masa kriris, ditambah lagi dengan sulitnya angkatan kerja baru mendapat pekerjaan di sektor formal, maka supplay tenaga kerja dan pengusaha ke sektor informal meningkat. Selain itu, relatif kuatnya daya tahan sektor informal selama krisis, juga dijelaskan oleh tingginya motivasi pengusaha untuk mempertahankan kelangsungan usahanya.

Dibanding sektor formal, khusunya usaha skala besar sektor informal yang pada umumnya adalah usaha skala kecil bersifat padat karya. Sementara itu persediaan tenaga kerja di Indonesia sangat banyak, sehingga upahnya relatif lebih murah jika dibandingkan dengan negara-negara lain dengan jumlah penduduk yang kurang dari Indonesia. Dengan asumsi faktorfaktor lain mendukung seperti kualitas produk yang dibuat baik dan tingkat efisiensi usaha serta produktivitas pekerja tinggi, maka upah murah merupakan salah satu keunggulan komparatif yang dimiliki usaha kecil di Indonesia.

Bila dilihat dari jenis-jenis produk yang dibuat di industri kecil (IK) dan industri rumah tangga (IRT) di Indonesia, dapat dikatakan bahwa produk-produk yang mereka buat pada umumnya sederhana dan tidak membutuhkan pendidikan formal, tetapi membutuhkan keahlian khusus. Disinilah keunggulan lain sektor informal, yang selama ini terbukti bisa membuat masyarakat bertahan meskipun persaingan dari sektor formal, termasuk impor sangat tinggi. Keahlian khusus tersebut biasanya dimiliki pekerja dan pengusaha secara turun temurun dan dari genarasi ke generasi.

Kebanyakan pengusaha di sektor informal menggantungkan diri pada uang (tabungan) sendiri, atau dana pinjaman dari sumber- sumber informal (diluar sektor perbankan/keuangan) untuk kebutuhan modal kerja dan investasi mereka. Meskipun banyak juga pengusaha-pengusaha kecil yang memakai fasilitas-fasilitas kredit khusus dari pemerintah. Selain itu, investasi di sektor informal rata-rata jauh lebih rendah daripada investasi yang dibutuhkan sektor formal. Tentu besarnya investasi bervariasi menurut jenis kegiatan dan skala usaha.

\section{Kelemahan Sektor Informal}

Sebagian besar industri kecil, terlebih industri rumah tangga di Indonesia adalah sektor informal . Masalah yang paluang besar yang dialami mereka adalah keterbatasan modal dan pemasaran. Masalah lainnya adalah pengadaan bahan baku, kurangnya keahlian dalam jenis-jenis teknis produksi tertentu, dan kurang keahlian dalam pengelolaan. Dan persoalan lainnya adalah mereka menghadapi 
persaingan yang tajam dan kemampuan mereka berkomunikasi sangat rendah, termasuk akses mereka ke fasilitas-fasilitas untuk berkomunikasi sangat terbatas.

Dalam hal persaingan, industri kecil dan industri rumah tangga menghadapi persaingan sangat ketat, baik dari industri menengah dan besar (IMB) maupun dari barang-barang impor. Persaingan itu tidak saja dalah hal kualitas dan harga, tetapi juga dalam pelayanan- pelayanan setelah penjualan dan penampilan produk. Dengan berbagai keterbatasan yang ada, mulai dari keterbatasan dana, skil, hingga kesulitan mendapatkan bahan baku dengan kualitas baik, membuat banyak industri kecil dan industri rumah tangga di Indonesia kesulitan meningkatkan kualitas produk mereka agar mampu bersaing di pasar domestik dan ekspor.

\section{$\underline{\text { Tinjauan Empiris }}$}

1. Erni Febriana Harahap (2016) yang berjudul Model Karakteristik dan Peranan Pekerja Informal di Kota Padang. Penelitian ini menggunakan metode pendekatan kualitatif deskriptif dan kualitatif untuk mengidentifikasi pelaku PKL (Pedagang Kaki Lima) dan bagaimana persepsi terhafap PKL yang ada di kota Padang. Berdasarkan penelitian peneliti menemukan beberapa hasil yaitu, PKL adalah penduduk asli kota Padang yang tingkat pendidikannya paling banyak SLTP dan SLTA sederajat yang memiliki usia 31 sampai 68 tahun dan kebanyakan yang sudah menikah. Jenis usaha yang paling banyak di lakukan adalah menjual makanan yang rata-rata lamanya usaha dijalankan selama 4 tahun yang bekerja sendiri atau memiliki tenaga kerja tidak lebih dari 2 karyawan dan memiliki kondisi sehat serta untuk mendirikan usaha yang digunakan adalah modal sendiri.

2. Padang Rihim Siregar yang berjudul Profil Sektor Informal (Studi Pedagang Kaki Lima di Jalan Hang Tuah Kota TanjungPinang. Penelitian ini menggunakan metode kualitatif yang akan dianalisis dengan metode frekuensi dan presentase untuk mengetahui kecenderungannya dan metode kualitatif akan digunakan untuk menganalisis dengan metode deskriptif . Berdasarkan penelitian dapat disimpulkan bahwa sebagian besar responden PKL adalah kaum migran dari luar kota TanjungPinang dan perpendidikan menengah. Mereka terjun ke sektor ekonomi informal karena ajakan keluarga dan mereka tidak ada pekerjaan lain di sektor formal. Data membuktikan bahwa sektor ekonomi informal ternyata memberikan penghasilan yang menurut mereka cukup tinggi dank arena sebagian besar dari mereka tidak mau beralih profesi lain, Dalam kaitannya regulasi, penelitian ini menemukan bahwa sebagian besar dari pelaku ekonomi informal tersebut tidak memahami peraturan pemerintah kota yang mengatur perilaku mereka namun tingkat ketaatan mereka terhadap peraturan cukup 
tinggi. Sebagian besar dari responden juga menyatakan bahwa mereka meminta izin kepada pihak pemerintah kota TanjungPinang sebagai pemilik lahan dimana mereka berjualan.

3. Direktoran Ketenagakerjaan dan Analisis Ekonomi yang berjudul Studi Profil Pekerja di Sektor Informal dan Arah Kebijakan keDepan. Penelitian ini menggunakan metode deskriptif analisis dan bersandar pada data sekunder survey angkatan kerja nasional (sakernas) 1989 dan 2002 dari BPS. Hasil dari kajian ini menunjukkan bahwa sebagian besar pekerja $(65,40$ persen $) \mathrm{di}$ Indonesia tahun 1998 berusaha di sektor informal, sisanya bekerja pdi sektor formal (34,60 persen). Keadaaan ini tidak semakin membaik pada tahun 2002 . Daoat dikatakan bahw aselama masa pemulihan ekonomi Indonesia periode 1998-2002, tidak ada perkembangan yang berarti dalamm penyerapan tenaga kerja yang bekerja di sektor formal. Sebaliknya justru sektor informal menyerap tenaga kerja. Kesimpulan lain adalah peran sektor informal relatif sangat tinggi dibanding sektor formal dalam menyerap tenaga kerja untuk jenis pekerjaan utama sebagai tenaga usaha penjualan.

4. Patrick C. Wauran yang berjudul Strategi Pemberdayaan Sektor Informal Perkotaan di Kota Manado. Penelitian ini menggunakan pendekatan kualitatif yang bersifat deskriptif analisis. Hasil dari penelitian ini yaitu menunjukkan bahwa pedagang keliling yang beroperasi di Kota Manado adalah para pedagang dari daerah khususnya pulau Jawa, disadari oleh para pedagang bahwa berusaha di sektor informal masih lebih baik penghasilannya dibandingkan bekerja di sektor lainnya seperti di pabrik. Pedagang keliling yang beroperasi di kawasan kota manado ini secara periodic pulang kampong setiap tahun sekali pad saat hari raya lebaran dan hampur seluruhnya tidak memiliki KTP manado, kebanyakan dari pedagang mengirimkan hasil kerja mereka ke kampong untuk keluarga mereka dan tidak mempunyai pemikiran untuk di simpan agar bis lebih mengembangkan usah amereka. Pemahaman pentingnya investasi masih sangat rendah bagi kebanyakan pedagang, permasalahan utama para pedagang sektor informal yaitu tidak adanya akses lembaga keuangan formal utuk kredit usaha, pemenuhan pembiayaan yang mendesak dilakukan para pedagang dengan memanfaatkan sumber pembiayaan informal, seperti kopeasi dan bank keliling walaupun mereka menyadari hal itu sangat beresiko. Para pedagang ini memiliki potensi usaha yang baik dan adanya kelayakan usaha yang baik secara ekonomi dan para pedagang belum menyadari manfaat dari pembentukan kelompok usaha.

5. Dharma Hammam Nur Mubarok (2016) yang berjudul Potensi Penerimaan retribusi Pelayanan Pasar dan Kontribusi Serta Prospeknya Terhadap Pendapatan 
Asli Daerah Kota Samarinda. Penelitian ini menggunakan metode statistik desktiptif . Metode ini menguji dan menilai setiap data yang berhasil dikumpulkan dengan menggunakan alat analisis potensi pasar, analisis tingkat kontribusi, dan analisis trend. Hasil dari penelitian ini potensi retribusi pasar di Kota Samarinda menunjukkan potensi pendapatannya yang sangat besar, dilihat dari hasil perhitungan potensi pasar dalam setahun. Hal ini menunjukkan bahwa potensi penerimaan retribusi pelayanan pasar berpengaruh positif terhadap nilai retribusi pelayanan pasar di Kota Samarinda, meskipun realisasinya di setiap tahun masih belum melampaui total potensi yang ada. Realisasi retribusi pelayanan pasar dari tahun ke tahun menunjukkan peningkatannya dan berpengaruh positif terhadap nilai pendapatan asli daerah Kota samarinda, meskipun kontribusi retribusi pelayanan pasar menunjukkan indikatornya yang sangat kurang disetiap tahunnya. Berdasarkan hasil analisis trend dengan pengelolaan data yang dilakukan secara manual memperoleh hasil analisis trend terhadap retribusi pelayanan pasar Kota Samarinda, dengan prospek yang bergerak positif (meningkat) selama 5 tahun yang akan datang yaitu periode 2015 sampai dengan tahun 2019.

\section{$\underline{\text { Definisi Konsep }}$}

1. Demografi merupakan istilah yang berasal dari dua kata Yunani, yaitu demos yang berarti rakyat atau penduduk dan graphein yang berarti menggambar atau menulis. Oleh karena itu, demografi dapat diartikan sebagai tulisan atau gambaran tentang penduduk, terutama tentang kelahiran, perkawian, kematian dan migrasi. Demografi meliputi studi ilmiah tentang jumlah, persebaran geografis, komposisi penduduk, serta bagaimana faktor-faktor ini berubah dari waktu kewaktu. Istilah ini dikemukakan pertama kali oleh Archille Guliard pada ahun 1855 dalam karyanya yang berjudul "elements de statistique humaine, ou demographie comparree" atau elements of human statistics or comparative demography (dalam Iskandar,1994). Dalam penelitian ini demografi yang dimaksud yaitu demografi pemilik usaha pekerja sektor informal.

2. Usaha adalah bentuk usaha yang melakukan kegiatan secara tahap dan terus-menerus agar mendapatkan keuntungan, baik yang dilakukan oleh individu maupun kelompok yang berbentuk badan hukum atau tidak berbentuk badan hukum, didirikan dan bekedudukan disuatu tempat (Harmaizar).

3. Tenaga kerja adalah setiap orang yang dapat melakukan pekerjaan guna menghasilkan barang dan jasa baik untuk memenuhi suatu kebutuhan sendiri maupun masyarakat (Undang-Undang 
Nomor 13 Tahun 2003 tentang Ketenagakerjaan).

4. Modal adalah hak atau bagian modal adalah kekayaan perusahaan yang terdiri atas kekayaan yang disetor atau yang berasal dari luar perusahaan dan kekayaan itu hasil dari aktivitas perusahaan itu sendiri (Munawir, 2016 : 19).

5. Masalah merupakan kesenjangan antara harapan dengan kenyataan , antara kebutuhan dengan yang tersedia, antara yang seharusnya dengan yang ada Menurut Suryabrata (1994: 60). Permasalahan usaha dalam penelitian ini yaitu dapat dilihat dari sisi kesulitan yang dihadapi serta fluktuasi usaha pekerja informal.

6. Potensi berasal dari bahasa latin yaitu potenia yang artinya kemampuan . Potensi adalah kemampuan untuk mempunyai kemungkinan untuk dikembangkan (Pakhi Pamungkas, 1997). Retribusi Daerah adalah pungutan sebagai pembayaran atas jasa atau pemberian izin tertentu yang khusus disediakan dan diberikan oleh pemerintah daerah, untuk kepentingan orang pribadi atau badan (Mardiasmo, 2015 : 15).

\section{METODE PENELITIAN}

Desain penelitian ini menggunakan metode deskriptif dengan pendekatan kualitatif dan kuantitatif . Metode deskriptif adalah suatu metode yang berfungsi untuk mendeskripsikan atau memberi gambaran terhadap objek yang diteliti melalui data atau sampel yang telah terkumpul sebagaimana adanya tanpa melakukan analisis dan membuat kesimpulan yang berlaku untuk umum (Sugiyono,2009:29). Metode kualitatif digunakan untuk menganalisis data yang bersifat presentase untuk mengetahui kecenderungannya, dan metode kualitatif digunakan untuk mendeskripsikan presentase yang diperoleh.

\section{Objek, Lokasi Penelitian dan Waktu Penelitian}

Objek dari penelitian ini adalah karakteristik pekerja informal dan potensi retribusi pelayanan pasar di kawasan pertokoan THM Kota Tarakan. Lokasi penelitian ini di laksanakan di Kota Tarakan, Kalimantan Utara. Sedangkan waktu penelitian ini dilakukan pada bulan juli-agustus 2018.

\section{$\underline{\text { Populasi dan Sampel }}$}

Populasi adalah wilayah generalisasi yang terdiri atas subjek atau objek dengan kualitas dan karakteristik tertentu yang ditetapkan oleh peneliti untuk dipelajari dan kemudian ditarik kesimpulan (Sangadji dan Sopiah, 2010:185). Setelah dilakukan observasi awal populasi dalam penelitian ini adalah pedagang di kawasan pertokoan THM sebanyak 335 pedagang dari 20 jenis usaha.

Sampel adalah bagian dari jumlah karakteristik yang diambil oleh populasi (Sangadji \& Sopiah, 2010:186).

Jumlah sampel dalam penelitian ini terdiri dari 183 pedagang di kawasan pertokoan 
THM Kota Tarakan. Sampel ditentukan dengan rumus slovin (Sudjarwo \& Basrowi, 2009:269) yakni sebagai berikut:

$$
\mathrm{n} \quad=\mathrm{N} /\left(1+\mathrm{Ne}^{2}\right)
$$

Keterangan:

$$
\begin{array}{ll}
1 & =\text { konstanta } \\
\mathrm{n} & =\text { ukuran sampel } \mathrm{N}=
\end{array}
$$

ukuran populasi

e2 = kelonggaran ketidaktelitian karena kesalahan pengambilan sampel yang dapat ditolerir yakni 5\% dengan tingkat kepercayaan $95 \%$.

$$
\begin{aligned}
\mathrm{n} & =335 /\left(1+335.0 .05^{2}\right) \\
& =183
\end{aligned}
$$

\section{$\underline{\text { Data Penelitian }}$}

Data yang digunakan adalah data primer dan data sekunder. Data primer merupakan sumber data penelitian yang diperoleh secara langsung dari sumber asli (tidak melalui perantara) (Sangadji \& Sopiah, 2010:171). Data primer penelitian ini diperoleh langsung dari pelaku sektor informal yaitu pedagang yang ada di komplek pertokoan THM Kota Tarakan melalui kuisioner. Sedanglan data sekunder merupakan data yang tidak langsung memberikan data kepada peneliti, misalnya harus melalui orang lain atau mencari melalui dokumen (Sugiyono, 2005:62). Data sekunder penelitian ini diperoleh dari instansi atau dinas yang terkait yaitu Dinas Perdagangan, Koperasi dan UMKM Kota Tarakan.

\section{$\underline{\text { Teknik Pengumpulan Data }}$}

1. Metode Angket/Kuisioner
Kuisioner adalah sejumlah pertanyaan tertulis yang digunakan untuk memperoleh informasi dari responden dalam arti laporan tentang pribadinya, atau hal-hal yang ia ketahui (Suharsimi Arikunto $(2006,152)$.

2. Metode Dokumentasi

Metode dokumentasi adalah metode pengumpulan data dengan mencari data mengenai hal-hal atau variable yang berupa catatan trankrip, buku, dokumen, peraturanperaturan, notulen rapat, agenda dan sebagainya

(Suharsimi

Arikunto,2006)

Tujuan dari penelitian deskriptif ini adalah untuk membuat deskripsi, gambaran, atau lukisan secara sistematis, faktual dan akurat mengenai fakta- fakta, sifat-sifat serta hubungan antar keadaan yang diselidiki.

2. Analisis Deskriptif

Teknik analisis data deskriptif dengan pendekatan kualitatif dilakukan untuk melihat latar belakang tumbuhnya pekerja informal, faktor yang mempengaruhi pendapatan pekerja informal, dan permasalahan serta fluktusai usaha

3. Analisis Persentase

Analisis data dengan pendekatan kuantitatif, untuk melihat dari segi demografi usaha, aspek usaha,aspek tenaga kerja, dan aspek keuangan penelitian ini menggunakan metode persentase .

4. Analisis Potensi Retribusi Pasar

Potensi yang dihitung adalah potensi retribusi pelayanan pasar berdasarkan dalam waktu satu tahun. Perhitungan ini bertujuan untuk mengetahui seberapa besar potensi penerimaan di kawasan pertokoan THM Kota Tarakan dengan 
menggunakan rumus dasar perhitungan potensi retribusi pasar selama setahun (Mahmudi, 2010)

Dengan menggunakan rumus di atas dimasukkan kedalam perhitungan potensi retribusi pelayanan pasar, dengan berdasarkan besaran tarif retribusi pelayanan pasar pada Peraturan Daerah Kota Tarakan Nomor 1 Tahun 2012 Tentang Retribusi Jasa Umum.

\section{HASIL PENELITIAN}

\section{Deskripsi Variabel Penelitian}

Data yang dikumpulkan dalam penelitian ini merupakan data primer yang diperoleh melalui penyebaran kuisioner terhadap pekerja informal sebanyak

183 responden yang sebelumnya telah dilakukan observasi sebanyak 335 pedagang yang terdiri dari 20 jenis usaha di Kawasan Pertokoan THM Kota Tarakan.

Data yang terkumpul setelah dilakukan pengolahan data terhadap 183 kuisioner yang telah di sebar adalah sebagai berikut:

$\underline{\text { Responden Berdasarkan Jenis }}$ $\underline{\text { Kelamin }}$

Dari 183 orang responden, terdapat 112 responden dengan jenis kelamin laki-laki $(61,20 \%)$ dan 71 responden dengan jenis kelamin perempuan $(38,80 \%)$. Berdasarkan data di tersebut laki-laki lebih mendominasi menjalankan usaha dibandingkan dengan perempuan.

Responden Berdasarkan Tingkat Usia

Usia responden yang menjalankan usaha berada pada usia produktif yaitu 23 tahun hingga 55 tahun. Faktor usia memiliki pengaruh yang besar terhadap kemampuan menjalankan dan mengelolah usaha karena berkaitan dengan pengetahuan dan pengelolaan keuangan. Karakteristik berdasarkan usia yaitu, usia $\leq 30$ tahun sebanyak 20 responden $(10,93 \%)$, usia antara 31 sampai dengan 40 tahun sebanyak 85 responden $(46,45 \%)$, usia antara 41 tahun sampai dengan 50 tahun terdapat 66 responden $(36,06 \%)$, sedangkan usia antara 51 tahun sampai dengan 55 tahun sebanyak 12 responden (6,56\%). Dari data tersebut dapat dilihat bahwa sebagian besar usia responden adalah usia antara 31- 40 tahun.

Responden Berdasarkan Tingkat $\underline{\text { Pendidikan }}$

Tingkat pendidikan yaitu terdapat 22 responden $(12,02 \%)$ yang berhasil menyelesaikan pendidikan Sekolah Dasar (SD), 56 responden $(30,60 \%)$ dengan pendidikan Sekolah Menengah Pertama (SMP), 70 responden $(38,25 \%) \quad$ dengan pendidikan Sekolah Mengengah Atas (SMA), dan 8 responden $(4,37 \%)$ menyelesaikan pendidikan pada bangku kuliah Diploma (D3), serta 27 responden (14,76\%) menyelesaikan pendidikan Strata (S1). Dari data tersebut dapat dilihat bahwa responden di dominasi pada tingkat pendidikan SMA, SMP, dan SD. Artinya pekerjaan pada sektor informal tidak memerlukan tingkat pendidikan yang tinggi dan merupakan lapangan pekerjaan yang mudah dilakukan meskipun dengan tingkat pendidikan yang rendah. 
$\underline{\text { Responden Berdasarkan Jenis Suku }}$

\section{Berdasarkan}

suku menunjukkan bahwa dominan pelaku sektor informal di kawasan pertokoan THM Kota Tarakan adalah penduduk dengan suku Bugis yaitu sebanyak 104 responden $(56,83 \%)$, dengan terbanyak ke dua adalah suku Jawa yaitu 59 responden $(32,24 \%)$, kemudian suku Bulungan yaitu sebanyak 6 responden $(3,28 \%)$, suku banjar sebanyak 5 responden (2,73\%), China sebanyak 4 responden $(2,18 \%)$, suku Tidung 3 responden $(1,64 \%)$, kemudian yang paling sedikit adalah suku padang dan batak yaitu masing-masing 1 responden $(0,55 \%)$. Berdasarkan tabel di atas dapat di lihat bahwa sebagian besar responden berasal dari suku bugis.

Responden Berdasarkan Status $\underline{\text { Perkawinan }}$

Karakteristik responden bila dilihat dari status perkawinan menunjukkan 165 responden (90,16\%) menikah dan 18 responden $(9,84 \%)$ yang belum menikah. Dari tabel di atas dapat dilihat bahwa sebagian besar responden adalah yang sudah menikah.

Responden Berdasarkan Jumlah Tanggungan Keluarga

Dari tingkat jumlah tanggungan keluarga terdapat 10 responden $(5,46 \%)$ yang tidak atau belum memiliki tanggungan dalam keluarga, 15 responden $(8,20 \%)$ memiliki 1 orang tanggungan keluarga, 51 responden $(27,87 \%)$ memiliki 2 orang tanggungan keluarga, 62 responden $(33,88 \%)$ memiliki 3 orang tanggungan keluarga, kemudian 38 responden $(20,77 \%)$ dengan jumlah tanggungan keluarga 4 orang, terakhir jumlah tanggungan keluarga sebanyak 5 orang yaitu hanya 7 responden $(3,82 \%)$. Dari data di atas dapat dilihat bahwa sebagian besar jumlah tanggugan dalam keluarga responden adalah 3 orang.

Responden Berdasarkan Jenis Usaha dan Jenis Barang yang di

Perdagangkan

Berikut adalah tabel 1 yang memperlihatkan distribusi responden berdasarkan jenis usaha.

Tabel 1. Distribusi Responden Berdasarkan Jenis Usaha

\begin{tabular}{|c|l|c|c|}
\hline No & \multicolumn{1}{|c|}{$\begin{array}{c}\text { Jenis } \\
\text { Usaha }\end{array}$} & Jumlah & $\%$ \\
\hline 1. & Konveksi & 83 & 45,36 \\
\hline 2. & $\begin{array}{l}\text { Konveksi } \\
\text { PKL }\end{array}$ & 23 & 12,57 \\
\hline 3. & Buah & 7 & 3,83 \\
\hline 4. & $\begin{array}{l}\text { PKL } \\
\text { Makanan }\end{array}$ & 12 & 6,56 \\
\hline 5. & Bordir & 4 & 2,19 \\
\hline 6. & $\begin{array}{l}\text { Pangkas } \\
\text { Rambut }\end{array}$ & 4 & 2,19 \\
\hline 7. & $\begin{array}{l}\text { Warung } \\
\text { Makan }\end{array}$ & 12 & 6,56 \\
\hline 8. & Elektronik & 4 & 2,19 \\
\hline 9. & Salon & 2 & 1,09 \\
\hline 10. & Taylor & 4 & 2,19 \\
\hline 11. & $\begin{array}{l}\text { Plasytatio } \\
\text { n }\end{array}$ & 11 & 6,01 \\
\hline 12. & Parfum & 2 & 1,09 \\
\hline 13 & $\begin{array}{l}\text { Stempel/S } \\
\text { ablon }\end{array}$ & 2 & 1,09 \\
\hline 14 & Sembako & 3 & 1,64 \\
\hline 15. & $\begin{array}{l}\text { Jasa } \\
\text { Travel }\end{array}$ & 2 & 1,09 \\
\hline 16. & Percetakan & 2 & 1,09 \\
\hline & & & \\
\hline
\end{tabular}


Tabel 1. Distribusi Responden Berdasarkan Jenis Usaha (Lanjutan)

\begin{tabular}{|c|l|c|c|}
\hline 17. & $\begin{array}{l}\text { Tukang } \\
\text { Gigi }\end{array}$ & 1 & 0,55 \\
\hline 18. & Laundry & 1 & 0,55 \\
\hline 19. & Konter & 3 & 1.64 \\
\hline 20. & Bengkel & 1 & 0,55 \\
\hline \multicolumn{2}{|l|}{ Jumlah } & 183 & 100 \\
\hline
\end{tabular}

Sumber: Data Primer Diolah, 2018.

Berdasarkan tabel 1 responden berdasarkan jenis usaha yang paling banyak adalah usaha konveksi yaitu 83 responden $(43,25 \%)$ jenis barang yang diperdagangkan pada jenis usaha konveksi adalah berbagai macam jenis pakaian seperti pakaian jadi laki- laki dan perempuan, pakaian sekolah, hijab, jeans, sepatu tas dan perabotan rumah tangga. PKL dengan jenis konveksi adaalah sebanyak 23 responden (12,57\%), Jenis usaha buah-buahan yaitu sebanyak 7 respondenn $(3,83 \%)$ buah yang diperdagangkan berbagai macam jenis seperti apel, anggur, semangka dan buah-buahan lainnya. PKL makanan sebanyak 12 responden $(6,56 \%)$ makanan yang diperdagangkan adalah jenis makanan dan minuman seperti nasi lalap, soto ayam, gorengan, dan es campur. Jenis usaha bordir sebanyak 4 responden $(2,18 \%)$, jenis usaha ini menyediakan jasa pembuatan nama, pemasangan lambing pada pakaian serta jasa jahit pakaian. Jenis usaha pangkas rambut sebanyak 4 responden $(2,18 \%) \quad$ khusus menyediakan jasa potong rambut bagi laki- laki dan perempuan. Jenis usaha kuliner atau warung makan sebanyak 12 responden $(6,56 \%)$ yang memperdagangkan berbagai macam makanan dan minuman berbeda dengan PKL makanan, warung makan ini responden menempati tempat seperti kios maupun los bangunan pasar dan usaha ini relatif lebih besar. Jenis usaha elektronik sebanyak 4 responden $(2,19 \%)$ memperdagangkan barang elektronik sperti lampu, senter, kipas angina dan sebagainya. Jenis usaha salon sebanyak 2 responden $(1,09 \%)$ jenis usaha ini menyediakan jasa perawatan tubuh yang lebih lengkp termasuk potong rambut. Jenis usaha taylor sebanyak 4 responden $(2,19 \%)$ jenis usaha ini menyediakan jasa pemesanan jahit seperti baju, celana dan sejenisnya. Jenis usaha playstaion sebanyak 11 responden $(6,01 \%)$ jenis jasa ini menyediakan jasa seperti game online. Jenis usaha parfum sebanyak 2 responden $(1,09 \%)$ jenis usaha ini memperdagangkan wangi-wangian untuk pakaian. Jenis usaha stempel/sablon yaitu usaha yang membuat stempel dan sablon. Jenis usaha sembako sebanyak 3 responden $(1,64 \%)$ yang menjual berbagai macam jenis sembako seperti gula, beras, tepung minuman dan sebagainya. Jenis usaha travel berjumlah 2 responden $(1,09 \%)$ yang melayani pemesanan tiket pesawat, pelni dan menjual pulsa dan sejenisnya. Jenis usaha percetakan yaitu 2 responden $(1,09 \%)$ yang menyediakan jasa cetak foto dan fotokopy. Jenis usaha tukang gigi 1 responden $(0,55 \%)$ yanitu jasa pemasangan gigi palsu dan pemasangan behel gigi. Jenis usaha laundry 1 responden $(0.55 \%)$ yaitu jasa cuci pakaian. Jenis usaha konter 3 responden $(1,64 \%)$ yaitu jenis 
usaha yang menjual pulsa dan assesories handphone. Jenis usaha bengkel 1 responden $(0,55 \%)$ yaitu usaha jasa servis kendaraan. Dari data di atas dapat dilihat bahwa sebagian besar responden menjankan usaha pada jenis usaha konveksi.

Responden berdasarkan Status Kepemilikan Usaha

Pada umumnya pekerja sektor informal ini menjalankan usahanya sendiri yaitu sebanyak 175 orang $(95,63 \%)$ atau responden, kemudian di ikuti dengan berkelompok sebanyak 8 orang $(4,37 \%)$ atau responden. Dari data tersebut dilihat bahwa sebagian besar usaha yang dijalankan responden adalah milik mereka sendiri.

Responden Berdasarkan Usaha Sebelumnya

Sebelum menjalankan usaha yang sekarang para responden masing-masing memiliki pekerjaan sebelumnya, ada yang dulunya adalah seorang pengangguran, ada yang pernah menjadi pengusaha tambak lalu menjalankan usaha sekarang, ada pula yang menjalankan usaha tambak hingga sekarang sambil menjalankan usahanya. Kemudian yang pernah menjadi karyawan baik itu karyawan toko, karyawan hotel hingga karyawan di sebuah kantor. Ada yang pernah bekerja sebagai petani maupun nelayan, kemudian ada yang pernah penjalankan usaha seperti berjualan sembako, berjualan gorengan, berprofesi sebagai sales, dan ada pula yang sejak awal menjalankan usahanya hingga sekarang.

Responden Berdasarkan Motivasi Mendirikan Usaha
Dari kuisioner yang di isi responden ditemukan bahwa motifasi atau alasan responden mendirikan usaha yang dijalankan sekarang adalah selain dengan tujuan mencari nafkah untuk memenuhi kebutuhan keluarga, responden juga menganggap menjadi pedagang seperti yang dijalankan adalah hal yang menguntungkan karna dinilai menjadi pedagang adalah usaha yang bisa bertahan eksistensinya , terutama dalam berdagang pakaian dan makanan yang menjadi kebutuhan primer setiap orang. Selain itu alasan responden menjalankan usahanya juga dikarenakan untuk mendirikan usaha di zaman elektronik seperti sekarang sangatlah mudah selama mereka mempunyai modal yang memenuhi untuk membuka usaha yang di inginkan. Kemudian alasan responden memilih lokasi di Kawasan Pertokoan THM adalah karena tempat tersebut adalah pasar yang dianggap strategis untuk mendirikan usaha yang dekat dengan pusat kota, alasan lain adalah karena dekat dengan rumah mereka sehingga lebih efektif dalam menjalankan usahanya, kemudian alasan lain adalah ketersediaan lokasi yang membuat pedagang memilih THM sebagai tempat usaha.

$\underline{\text { Responden Berdasarkan Lama Usaha }}$

Responden yang baru memulai usaha yaitu 3 sampai dengan 6 bulan hanya ada 2 orang $(1,02 \%)$, menurut data yang ditemukan reponden yang baru memulai usaha tersebut adalah responden dengan usia 23 dan 25 tahun diantaranya adalah 
meneruskan usaha keluarga dan mendapatkan sumber modal dari orang tua. Kemudian dengan lama usaha $1-5$ tahun yaitu sebanyak 28 orang $(15,30 \%)$ atau responden, yang paling mendominasi adalah lama usaha 6 sampai dengan 10 tahun yaitu sebanyak 100 orang $(54,64 \%)$ atau responden, 11 sampai dengan 15 tahun yaitu sebanyak 48 orang $(26,22 \%)$ atau responden, dan terakhir yaitu 16 sampai dengan 20 tahun yaitu sebanyak 5 orang $(2,73 \%)$ atau responden . Dari data tersebut dapat dilihat bahwa sebagian besar responden menjalankan usaha selama 6 sampai dengan 10 tahun.

Distribusi Responden berdasarkan Jumlah Tenaga Kerja

Jumlah tenaga kerja pada sektor informal yang memiliki tenaga kerja dengan jumlah 1 orang yaitu sebanyak 41 orang atau responden $(22,40 \%)$, tenaga kerja dengan jumlah 2 orang yaitu sebanyak 52 orang atau responden $(28,41 \%)$, tenaga kerja dengan jumlah 3 orang yaitu sebanyak 36 orang atau responden $(19,67 \%)$, tenaga kerja dengan jumlah 4 orang yaitu sebanyak 15 orang atau responden $(8,19 \%)$, kemudian tenaga kerja dengan jumlah 5 orang yaitu sebanyak 4 orang atau responden $(2,18 \%)$, dan dengan jumlah 0 orang atau yang tidak memiliki tenaga kerja yaitu sebanyak 35 orang $(! 9,12 \%)$ artinya responden yang tidak memiliki tenaga kerja mereka menjalankan usaha sendiri dengan tidak mempekerjakan tenaga kerja lain untuk menghemat pengeluaran upah tenaga kerja. Dari data di atas dilihat bahwa sebagian besar responden memiliki 2 orang tenaga kerja.
Responden berdasarkan Hubungan dengan Tenaga Kerja

Hubungan pemilik usaha dengan tenaga kerja yaitu orang lain sebanyak 122 orang $(66,66 \%)$, sedangkan tenaga kerja yang memiliki hubungan keluarga dengan pemilik usaha yaitu sebanyak 26 orang $(14,20 \%)$, kemudian dengan jumlah 35 orang $(19,12 \%)$ adalah pemilik usaha yang tidak memiliki tenaga kerja. Dari data di atas dilihat bahwa sebagian besar hubungan antara pemilik usaha dengan tenaga kerja adalah orang lain.

Responden berdasarkan Keinginan Menambah Tenaga Kerja

Sebanyak 33 orang $(18,03 \%)$ atau responden ingin menambah jumlah tenaga kerjanya dikarenakan jumlah tenaga kerja yang mereka miliki saat ini masih kekurangan diantaranya kewalahan menghadapi pembeli di saat ramai dan ada pula yang belum memiliki tenaga kerja sehingga ingin mencari tenaga kerja . Kemudian sebanyak 120 orang $(65,57 \%)$ atau responden yang tidak ingin menambah lagi tenaga kerja mereka dikarenakan mereka menganggap jumlah tenaga kerja yang mereka miliki sekarang sudah cukup. Sementara dengan jumlah 30 orang $(16,39 \%)$ atau respoden adalah angka responden yang tidak memiliki tenaga kerja dengan alasan mereka masih sanggup menjalankan usaha sendiri tanpa bantuan tenaga kerja lain. Dari data di atas dapat dilihat bahwa sebagian besar responden tidak ingin menambah tenaga kerjanya. 


\section{$\underline{\text { Responden berdasarkan Jam Kerja }}$}

Jam kerja per hari, dengan jam kerja 6- 8 jam per hari yaitu sebanyak 22 responden (12,02\%), dengan jam kerja 9 - 11 jam per hari sebanyak 30 responden (16,39\%), kemudian dengan jam kerja $12-14$ jam dalam seharinya adalah yang paling dominan yaitu sebanyak 130 responden $(71,03 \%)$. Dari data di atas dapat dilihat bahwa sebagian besar responden bekerja 12 sampai dengan 14 jam dalam sehari. Umumnya para pekerja informal ini walaupun tidak terikat oleh jam kerja formal, namun mereka harus mendisiplinkan diri sendiri dalam menjalankan usahanya misalnya ketetapan waktu jam kerja.

Responden berdasarkan Upah Tenaga Kerja

Upah tenaga kerja yaitu Rp.1.0000.000 sampai dengan Rp. 1.100 .000 adalah sebanyak 37 responden $(20,21 \%)$, yang paling banyak dengan upah tenaga kerja Rp.1.200.000 sampai dengan Rp. 1.300.000 adalah sebanyak 91 responden $(49,72 \%)$, kemudian dengan upah Rp. 1.400.000 sampai dengan Rp. 1.500 .000 adalah sebanyak 14 responden $(7,56 \%)$, sedangkan 30 responden $(16,39 \%)$ adalah responden yang tidak mengeluarkan upah untuk tenaga kerja, karena tidak memiliki tenaga kerja. Kemudian upah dengan cara bagi hasil yaitu sebanyak 11 responden $(6,01 \%)$. Dari data di atas dapat dilihat bahwa sebagian besar responden memberikan upah kepada tenaga kerjanya yaitu sebesar Rp.1.00.000 sampai dengan Rp.1.300.000 .
Responden berdasarkan Naik atau Tidaknya Upah Tenaga Kerja

Dari hasil kuisioner yang di sebarkan kepada 183 responden, terdapat 142 responden $(76,50 \%)$ yang menyatakan bahwa setiap upah tenaga kerja akan terus mengalami kenaikan seiring waktu, sesuai dengan prestasi kerja masing-masing tenaga kerja. Hal tersebut terjadi dalam hitungan 3 bulan, 6 bulan dan 1 tahun. Sedangankan 11 responden $(6,01 \%)$ adalah pemilik usaha yang membagi hasil pendapatan, ketika pendapatan naik maka pembagian hasilnya juga meningkat atau sebaliknya ketika pendapatan menurut maka pembagian pendapatannya juga akan menurun, artinya naik turunnya pendapatan atau upah yang diterima tergantung dari hasil usaha setiap bulan. Sebanyak 30 responden tidak mempekerjakan tenaga kerja sehingga tidak perlu menggaji tenaga kerja, namun yang dilakukan responden adalah mereka memberi gaji mereka sendiri yaitu dengan menabung sebagian dari pendapatan mereka setiap bulannya.

$\underline{\text { Responden berdasarkan Sumber }}$ $\underline{\text { Modal }}$

Sumber modal awal menjalankan usaha yaitu dengan modal sendiri adalah sebanyak 123 responden $(67,21 \%)$, dengan pinjaman bank adalah sebanyak 39 responden $(21,31 \%)$, kemudian sumber modal dari pinjaman keluarga/pinjaman orang tua adalah sebanyak 21 responden $(11,47 \%)$. Dari data di atas dapat dilihat bahwa sebagian besar responden dalam 
memperoleh modal adalah dari modal mereka sendiri.

\section{$\underline{\text { Kendala dan Fluktuasi Usaha }}$}

Kendala atau hambatan yang di hadapi pekerja sektor informal di Kawasan Pertokoan THM Kota Tarakan dapat menghambat kinerja usaha dan mengurangi pendapatan yang diperoleh. Adapun kendalakendala yang dihadapi pekerja sektor informal adalah sebagai berikut:

a. Kendala persaingan

Dengan semakin berkembangnya zaman dan teknologi mendirikan usaha bukan hal yang dianggap sulit lagi oleh para pemuka usaha. Karena semakin mudahnya seseorang membuka usaha hal ini dianggap responden semakin tinggi pula persaingan pasar diantara pemilik usaha.

b. Kendala mahalnya biaya pengiriman barang.

Biaya pengiriman barang dianggap responden adalah kendala yang cukup menyulitkan, meskipun pengiriman barang saat ini sangatlah mudah dan cepat namun biaya pengirimannya dianggap cukup mahal yang secara langsung membuat harga barang yang diperjualbelikan juga menjadi lebih mahal, terutama di kota Tarakan hampir semua barang yang diperjualbelikan adalah dari luar kota.

c. Kendala Cuaca

Cuaca menjadi salah satu faktor alam yang tidak dapat dihindari. Hal ini menjadi faktor penghalang bagi responden terutama pagi pedagang kaki lima yang melapakkan dagangannya di pelataran atau halaman pasar.
Waktu

peningkatan pendapatan yang dirasakan oleh pekerja sektor informal adalah ketika peringatan hari-hari besar, seperti hari disaat menuju puasa dan lebaran, tahun baru, tahun ajaran baru untuk sekolah serta pada tanggal muda yaitu disaat masyarakat atau pembeli telah menerima gaji. Sedangkan penurunan pendapatan yang dirasakan oleh pekerja sektor informal adalalah pada waktu sebaliknya seperti hari -hari biasa dan disaat tanggal tua.

Analisis Potensi Penerimaan $\underline{\text { Retribusi Pasar }}$

Potensi yang dihitung adalah potensi retribusi pelayanan pasar berdasarkan dalam waktu satu tahun. Perhitungan ini bertujuan untuk mengetahui seberapa besar potensi penerimaan di kawasan pertokoan THM Kota Tarakan dengan menggunakan rumus dasar perhitungan potensi retribusi pasar selama setahun (Mahmudi, 2010) dengan rumus sebagai berikut:

Potensi $=\{($ Jumlah kios $\mathrm{x}$ TR $)+($ Jumlah LOS x TR) + (Jumlah KS x TR ) $\mathrm{x}$ ( E aktivitas pasar sebulan $\mathrm{x}$ 12) \}

$=[(148 \times 81.000)+(124 \times 72.000)$

$+(63 \times 60.000)] \times 12$

$=296.352 .000$

Berikut ini adalah tabel yang menunjukkan penerimaan potensi retribusi pelayanan pasar di Kawasan Pertokoan THM Kota Tarakan berdasarkan 355 reponden: 


\begin{tabular}{|c|c|c|c|c|c|}
\hline $\begin{array}{l}\text { Tal } \\
\text { Ret } \\
\text { Per }\end{array}$ & $\begin{array}{r}2 \\
\text { busi } \\
\text { koa }\end{array}$ & $\begin{array}{r}\text { Po } \\
\mathbf{P} \\
\text { THM }\end{array}$ & $\begin{array}{l}\text { nsi } \\
\text { sar } \\
\text { Kota }\end{array}$ & $\begin{array}{r}\text { Pener } \\
\text { Ka } \\
\text { Tarak }\end{array}$ & $\begin{array}{l}\text { aan } \\
\text { isan }\end{array}$ \\
\hline No & $\begin{array}{c}\text { Jenis } \\
\text { Bangu } \\
\text { nan }\end{array}$ & $\begin{array}{l}\text { Jumlah } \\
\text { Sampel }\end{array}$ & $\begin{array}{c}\text { Tarif/ } \\
\text { Bulan } \\
\text { (Rupi } \\
\text { ah) }\end{array}$ & $\begin{array}{c}\text { Perhitu } \\
\text { ngan } \\
\text { Bulanan } \\
\text { (Dalam } \\
\text { Ribu } \\
\text { Rupiah) }\end{array}$ & $\begin{array}{c}\text { Perhitun } \\
\text { gan/Tah } \\
\text { un } \\
\text { (Dalam } \\
\text { Ribu } \\
\text { Rupiah) }\end{array}$ \\
\hline 1. & Kios & 148 & $\begin{array}{c}81.00 \\
0\end{array}$ & 11.988 & 143.856 \\
\hline 2. & Los & 124 & $\begin{array}{c}72.00 \\
0\end{array}$ & 8.928 & 107.136 \\
\hline 3. & $\begin{array}{c}\text { Pelatar } \\
\text { an/ } \\
\text { Halam } \\
\text { an }\end{array}$ & 63 & $\begin{array}{c}60.00 \\
0\end{array}$ & 3.780 & 45.360 \\
\hline & & 355 & & 24.696 & 296.352 \\
\hline
\end{tabular}

Sumber: Data Primer Diolah, 2018.

Potensi penerimaan retribusi pelayanan pasar di kawasan pertokoan THM Kota Tarakan dengan jumlah populasi 355 yaitu terbagi menjadi 148 jumlah kios dengan tarif retribusi perbulan sebesar Rp. 81.000 adalah Rp.11.988.000 dalam hitungan bulan sedangkan dalam hitungan tahun adalah Rp.143.856.000. Los 124 dengan tarif retribusi perbulan $\mathrm{Rp}$. 72.000 adalah Rp.8.928.000 dalam hitungan bulan sedangkan dalam hitungan tahun adalah Rp.107.136.000. Kemudian Pelataran/halaman 63 dengan tarif retribusi perbulan Rp. 60.000 adalah Rp. 3.780.000 dalam hitungan bulan sedangkan dalam hitungan tahun adalah Rp. 45.360.000.

Potensi penerimaan retribusi pelayanan pasar berdasarkan kios, los dan pelataran/halaman sebanyak 355 responden adalah $\mathrm{Rp}$. 296.352.000/ tahun. Rata-rata penerimaan setiap bulan adalah $\mathrm{Rp}$. 8.232 .000 , dan rata-rata peneriamaan setiap tahun adalah Rp. 98.784.000. Responden menyadari bahwa pembayaran retribusi adalah sebuah kewajiban yang harus di bayar karena selain lahan tersebut bukan milik mereka hal itu juga untuk kebaikan mereka dan untuk membangunan daerah, selain itu para responden juga menyatakan membayar uang kebersihan setiap bulannya yang sudah menjadi kewajiban mereka untuk kebersihan dan kebaikan mereka.

\section{KESIMPULAN}

Karakteristik yang paling banyak dari pekerja informal berdasarkan jenis kelamin yaitu lakilaki $(61,20 \%)$, berdasarkan usia 30 40 tahun (46,40\%), berdasarkan pendidikan yaitu SMA $(38,25 \%)$, berdasarkan suku yaitu bugis $(56,83 \%)$, berdasarkan status perkawinan yaitu sudah kawin (90,16\%), berdasarkan jumlah tanggungan keluarga yaitu 3 orang $(33,88 \%)$, berdasarkan jenis usaha yaitu konveksi (45,36\%), berdasarkan status kepemilikan yaitu milik sendiri $(95,63 \%)$, berdasarkan lama usaha yaitu $6-10$ tahun $(54,64 \%)$, berdasarkan jumlah tenaga kerja yaitu 2 orang $(28,42 \%)$, berdasarkan hubungan responden dengan tenaga kerja adalah orang lain $(66,66 \%)$, berdasarkan keinginan menambah tenaga kerja yaitu responden tindak ingin menambah tenaga kerja $(65,57 \%)$, berdasarkann jam kerja yaitu 12 - 14 jam sehari (71,03\%), berdasarkan upah tenaga kerja yaitu Rp.1.200.000 sampai dengan Rp. 1.400 .000 per bulan $(49,72 \%)$, upah tenaga kerja yang mengalami kenaikan $(76,50 \%)$, sumber modal yaitu modal sendiri $(67,21 \%)$.

Pada waktu peringatan harihari besar, dan liburan pekerja 
informal mengalami kenaikan dalam hal pendapatan namun kendalanya adalah persaingan yang ketat, biaya pengiriman barang yang cukup mahal, dan kondisi cuaca yang berubah-ubah.

Potensi penerimaan retribusi pelayanan pasar berdasarkan kios, los dan pelataran/halaman sebanyak 335 responden adalah $\mathrm{Rp}$. 296.352.000/ tahun, dan responden menganggap dengan membayar retribusi adalah sebuah kewajiban yang tujuannya adalah demi kepentingan mereka.

\section{SARAN}

Berdasarkan hasil dan pembahasan mengenai Karakteristik pekerja informal di Kawasan Pertokoan THM Kota Tarakan, saran yang dapat penulis sampaikan:

1. Di harapkan penelitian-penelitian selanjutnya ditambahkan variabel- variabel lainnya dan karakteristik-karakteristik yang lebih luas, di luar dari variable dan karakteristik pada penelitian ini.

2. Penulis mengharapkan penelitian selanjutnya dilakukan beberapa pasar yang ada di Kota Tarakan seperti Pasar Guser, Pasar Tenguyun, Pasar Beringin, Pasar Lingkas dan pasar-psar lainnya, sehingga membuat penelitian ini menjadi lebih kemplit dan luas.

3. Penulis mengharapkan dengan terbentuknya usaha-usaha pada sektor informal yang dimulai dari kecil suatu saat dengan semakin meningkatnya usaha dapat mengubah usaha informal menjadi usaha sektor formal yang dapat membuka luas lapangan pekerjaan.

\section{DAFTAR PUSTAKA}

Algifari. 2010. Statistika Deskriptif Plus Untuk Ekonomi dan Bisnis. Yokyakarta: Sekolah Tinggi Ilmu Manajemen YKPN.

BAPPENAS, 2009. Peran Sektor Informal Sebagai Katup Pengaman Masalah Ketenagakerjaan. Kajian Evaluasi Pembangunan Sektoral. Kedeputian Evaluasi Kinerja Pembangunan.

El Shaks, Salah, 1984. On City and The Contribution of The Informal Sector: Some Hypotheses.

Fukuci, Takao, 1998. A Simulation Analysis of The Urban Informal Sector, The Developing Economies, XXXVI-3.

Harahap, E. F. 2016, Model Karakteristik dan Peranan Pekerja Informal di Kota Padang, Jurnal Apresiasi Ekonomi. (Vol. 4 Nomor 3)

Hidayat. 1983. Definisi, Kriteria dan

Evaluasi Konsep Sektor

Informal: Sumbangan

Pemikiran untuk Repelita IV, Analisa tahun XII No. 7

Hidayat. 1978. Peranan Sektor Informal Dalam Struktur Perekonomian Daerah Yogyakarta. Pusat Penelitian Sumberdaya Manusia dan Lingkungan. Bandung: Universitas Padjadjaran.

Kasali, Rhenald, 2010, Sektor Informal Jadi Kekuatan 
Ekonomi.

Jakarta:

http:/yeaindonesia.com.

Mubarok. 2016. Potensi Penerimaan Retribusi Pelayanan Pasar dan Kontribusi Serta Prospeknya Terhadap Pendapatan Asli Darah Kota Samarinda. Samarinda, Jurnal Ekonomi, Manajemen dan Akuntansi. Vol. 18, No 2 Tahun 2016.

Moleong, Lexy, J. 2001. Metode Penelitian Kualitatif. Cetakan Keempat Belas. Bandung: PT. Remaja Rosda Karya.

Nazara, Suahasil. 2010. Ekonomi Informal di Indonesia : ukuran sampel, komposisi dan evolusi. Jakarta: ILO.

Perkasa, Andi, Agung. 2012. FaktorFaktor Yang Mempengaruhi Pola Konsumsi Mahasiswa UNHAS. Skripsi. Makassar . Fakultas Ekonomi Universitas Hasanuddin.

Potres, A dan Walton, J, 1981. Labor, Class and The International System. New York: Academic Press.

Rahardjo, Dawam, M. 2003. Peranan Pekerja dalam Pembangunan Ekonomi. Jakarta: LSPEUI.

Sangadji, Etta Mamang dan Sopiah. 2010. Metodologi Penelitian Pendekatan Praktis Dalam Penelitian. Yokyakarta: C.V Andi.
Sethuraman. 1982. The Urban Informal Sector in Developing Countries. New York: ILO

Sinaga, Anggiat, 2013. Analisis Tenaga Kerja Sektor Informal Sebagai Katup Pengaman Masalah Tenaga Kerja di Kota Medan. QE Journal Vol. 02- No.01

Sudjarwo dan Basrowi. 2009. Manajemen Penelitian Sosial. Bandung: Mandar Maju.

Suradi, 2011. Peranan Sektor Informal Dalam Penanggulangan Kemiskinan. Informasi, Vol. 16 No. 03 Tahun 2011

Tambunan, Tulus. 1998. Krisis Ekonomi Indonesia. Penyebab \& Penanggulangannya. Jakarta: LP3E KADIN Indonesia \& Yayasan Indonesia Forum

Undang-Udang Republik Indonesia Nomor 13 Tahun 2003 tentang ketenagakerjaan. Diambil dari:

http://www.kemenperin.go.id/ kompetensi/UU_13_2003.

diunduh pada tanggal 26 maret 2018, pukul 13.00 WIT.

Winanto, Asis Riat. 2005. Alternatif Pemberdayaan Pedagang Kaki Lima di Kabuipaten Ponorogo. Penelitian individu. Tidak dipublikasikan 